\title{
Promoting Transformative Learning and Education for Sustainable Development at Community Learning Centres in Japan
}

Prepared by: Khalaf Mohamed Abdellatif ${ }^{1,2}$, and Eisuke Hisai ${ }^{3}$

${ }^{1}$ Assistant Lecturer, Faculty of Graduate Studies for Education, Cairo University.

${ }^{2} \mathrm{Ph} . \mathrm{D}$. Researcher, Graduate School of Education, Hiroshima University.

${ }^{3}$ Associate Professor, Graduate School of Education, Hiroshima University.

Abstract: Individuals and governments seek a community where sustainability prevails. The discourse on transformative learning receives great attention on the global level because of its contribution to promoting sustainable development. In Japan, the activities of community learning centers (Kominkan) are argued to promote sustainability. This paper examines these activities to reveal their relationship with transformative learning and Education for Sustainable Development (ESD). It examines the learning group activities of the 71 Kominkans of Hiroshima city to provide a comprehensive image of community-based learning activities and reveal the relationship between transformation and sustainability. This paper argues that Kominkan activities can develop an integrative form of both community-based transformative learning and community-based transformative ESD. The paper is concluded by suggesting an integrative model of promoting transformation and sustainability through community-based learning activities in Kominkans.

Key words: Social Education in Japan, Community-based Learning, Transformative Learning Theory, Education for Sustainable Development

\section{Introduction}

Social education in Japan [equivalent to adult education in the Arab States] is recognized as a type of learning for self-fulfillments, such as hobbies, music, painting, dance, and cooking (Murata \& Yamaguchi, 2010; Kawano, Matsuda $\&$ Xiao, 2016). Kominkans, often known as community learning centers, are social education facilities. Their activities are generally known as communitybased learning activities (Maruyama, 2009; Oyasu \& Riewpituk, 2013). Selffulfilling activities have rapidly spread since the 1960 s, and have taken place in Kominkans (Kawano, Matsuda \& Xiao, 2016). Many Kominkans offer activities that promote sustainability and community development, and consequently, 
Kominkans have fast become key facilities in promoting sustainability and societal transformation through their activities (Oyasu \& Riewpituk, 2013).

ESD is argued to be a transformational education approach that aims to achieve a sustainable future (UNESCO, 2014; UNESCO, 2020), while transformative learning redefines the concepts of knowledge and experience to give more opportunities for self-understanding (Mezirow \& Taylor, 2009). Wals (2010) argues that education for sustainability is the "creation of space for transformative social learning". However, much uncertainty still exists about the relation between transformative learning and ESD.

This relation has been recently examined in literature on the context of formal education (Chikamori, Tanimura, \& Ueno, 2019; Schnitzler, 2019; Souza, Wals \& Jacobi, 2019), however, the context of non-formal education has received less attention. In this paper, therefore, I discuss community-based learning activities of Kominkans, as one of the most popular forms of non-formal education in Japan, in the light of transformative learning theory and education for sustainable development.

This paper focuses on the context of social education in Hiroshima city, particularly the focus is on Kominkans' learning group activities. The primary aim of this paper is to reveal the relation between community-based transformative learning and ESD at Kominkans. To this end, the learning group activities of all 71 Kominkans of Hiroshima city were examined to elicit this relation.

This paper is structured in the following way. After reviewing the context of transformative learning, it looks at the current context of ESD in relation to community-based learning. This is followed by a discussion on the link between both community-based transformative learning and community-based ESD. The paper then turns to examine the case of Hiroshima city, starting with the nature of Kominkan activities. Based on the case of Hiroshima city, this paper concludes with a suggested integrative model for promoting transformation and sustainability on the local community's level.

\section{Community-based Transformative Learning}

Transformative learning provides a constructive change of our knowledge and ability to use this knowledge in the future, as well as it provides a deeper understanding of our experiences and how we understand ourselves in relation to our community (Cranton, 2006; Mezirow \& Taylor, 2009) and identity (Illeris, 2014). While community-based transformative learning describes the collective transformative learning of and among a certain group of learners with common interests and identities in a certain community (Mejiuni, 2012).

Since 1978, Mezirow's theory of transformative learning has evolved "into 
a comprehensive and complex description of how learners construe, validate, and reformulate the meaning of their experience" (Cranton, 2006; Illeris, 2014). Mezirow (1997) explains "defining condition of being human is that we have to understand the meaning of our experience", he states that one of the transformative learning goals is to acquire autonomous thinking competence (Mezirow, 2012).

According to Mezirow (2012), being a transformative learner involves transforming habits of mind to be critically reflective, redefining the problematic situations, adopting new forms of evaluation in the light of reflective insights. Mezirow $(2009 ; 2012)$ explains the process of perspective transformation:

1. A disorienting dilemma;

2. Self-examination;

3. A critical assessment of assumptions;

4. Recognition of transformation;

5. Exploration of options for new actions;

6. Planning for action;

7. Acquiring knowledge and skills;

8. Provisional trying of new roles;

9. Building competence and self-confidence; and

\section{A reintegration}

From the above-mentioned steps, the process of perspective transformation follows a process that involves thinking, planning, and transformation. This procedure aims to build experience or competence that will be used in a future situation. Reintegration is the action when learners can develop a new frame of reference and reintegrate their knowledge, skills, and attitudes into practice (Kligyte, 2011). From a community-based transformative learning point of view, reintegration can be understood as a structured transformation of practices to achieve community development and well-being.

\section{Education for Sustainable Development}

Most of the countries across the world face many challenges, including environmental, social, and economic challenges. Wals, Mochizuki, and Leicht (2017) argue that the transformation towards sustainable societies is the major role of education and lifelong learning. The process of integrating education into sustainable development contributes to achieving a learning society and 
sustainability (Didham \& Ofei-Manu, 2015).

\section{1. What is Education for Sustainable Development?}

ESD is an educational activity that encourages changes in knowledge, skills, values, and attitudes to promote community development (Tanaka, 2009). it is based on the multi-disciplinarity of knowledge, which includes "environmental awareness of ecosystems and natural resources, their importance and limitations, the threats that human activities present to them, and build the skills necessary for monitoring, analysis, and intervention" (Blewitt, 2008). Besides this environmental pillar, ESD comprises economic and social pillars (Blewitt, 2008; UNESCO, 2014).

ESD is seen as a transformative learning approach aiming to develop learner's knowledge along with a conceptual understanding of the environment (Summers \& Cutting, 2016). It is a holistic and transformational education that aims to achieve a sustainable society (UNESCO, 2014; UNESCO, 2020).

Despite sustainable development has become increasingly visible at all levels of education, it is still a developing concept (Summers \& Cutting, 2016). There is, however, no global agreement on how sustainable development should be implemented. Nonetheless, there is a consensus that sustainable development should be promoted through education (Tanaka, 2009).

\section{2. Brief History of Education for Sustainable Development}

In 1987, the term 'sustainable development' was coined in the Brundtland report (UN-WCED, 1987). Sustainable development has achieved a global consensus through the 1992 Rio de Janeiro Earth Summit, at which the United Nations Agenda 21 was formulated to promote ESD. Furthermore, in the 2002's Johannesburg Summit and UN general assembly, Japan proposed that the decade $(2005$ - 2014) to be the Decade of Education for Sustainable Development (DESD) (Tanaka, 2017). Since then, Japan has been actively promoting ESD in formal and non-formal education facilities (Maruyama, 2011; Okano, 2016).

In August 2015, the Japanese ESD Special Subcommittee issued For Further Promotion of ESD report which highlighted outcomes from previous ESD activities and suggested the "promotion of the participation in ESD of social education facilities" (JNCU, 2015). In September 2015, 193 countries committed to the new sustainable development agenda. 169 targets for the 17 Sustainable Development Goals (SDGs) were approved and hence the UN resolution 70/1 was adopted (UN, 2015). Article 25 of the SDGs agenda emphasizes that "all people [...] should have access to life-long learning opportunities that help them to acquire the knowledge and skills needed to exploit opportunities and to participate fully in the society" (UN, 2015).

Education is the topic of goal 4 from SDGs, it is implicitly included in all 
SDGs (Rogers, 2019), and explicitly included in the following SDGs targets: 3.7, 8.6, and 13.3 (UN, 2015). In March 2016, the Ministry of Education, Sports, Science, and Technology in Japan (MEXT) has issued A Guide to Promoting ESD to provide an in-depth understanding of ESD. Mochizuki (2017) clarifies that promoting sustainable development at Kominkans has gone through three chronological steps over time: First, social change movements during Taisho and Showa periods (1912-1989); second, the transformation of environmental education; and third, community and place-based approaches to ESD.

\section{Community-based Approach for Linking Transformative Learning to ESD}

This section discusses the community-based learning approach of Kominkans' activities to understand the link between transformative learning and ESD. Kominkan activities empower participants to practice a unique form of community-based transformative learning. Participation in community-based learning activities is voluntary and autonomous. Critical reflection along with building and modifying experiences are central to understanding the perspective transformation in such context. Through most community-based learning activities, participants can build competencies and knowledge through critical reflection to use them in future situations.

On the other hand, Kominkans as social education facilities have their approach to promoting community-based ESD through learning activities (JNCU, 2015). It is important to review community-based ESD through the lens of the wide meaning of ESD. In general, Kominkan activities appear to be social activities of hobbies and recreation. However most of these activities are not introduced for Kominkan users as ESD activities, it deals with at least one pillar of ESD. Hence, this research discusses the learning group activities of Hiroshima city Kominkans from this point of view.

Noguchi, Guevara, and Yorozu (2015) discuss six action principles towards ESD vision, the current research adopts repositioning these principles to the context of community-based ESD as following:

- Responding: Solving local community issues that hinder achieving sustainable development;

- Engaging: Networking with multi-stakeholders to respond to the community issues identified;

- Enabling: Empowering community to achieve sustainability;

- Embedding: Including the principles of ESD in community-based learn- 


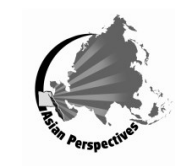

ing activities;

- Sustaining: Long-term changes and sustainable achievements; and

- Transforming: Directing practices and policies towards a sustainable future.

- Summarizing the results of the literature review, Table (1) shows community-based activities through the lenses of ESD and transformative learning.

Table 1 Aim, vision, and principles of community-based activities

In this sense, the fundamental premise of ESD and transformative learning is that their community-based approach is based on critical thinking and perspective transformation. In this context, critical thinking as a competence comprises knowledge to think critically; cognitive skills of analyzing, synthesizing, and evaluating knowledge; and attitudes towards being a critical thinker (Taimur \& Sattar, 2020). While transformational competencies are inclusive development of skills, experiences, and building capacities "to promote innovation, creativity, and entrepreneurship" for community development (Saffa \& Jabbie, 2020).

\section{The Case of Kominkans at Hiroshima City}

Hiroshima city is the capital of Hiroshima prefecture, it comprises eight wards: Aki, Asakita, Asaminami, Higashi, Minami, Naka, Nishi, and Saeki ward. The population of Hiroshima city was 1,195,572 in April 2020 (The City of Hiroshima, 2020).

\begin{tabular}{|l|l|l|}
\hline & Community-based ESD & $\begin{array}{l}\text { Community-based transforma- } \\
\text { tive learning }\end{array}$ \\
\hline Aim & Sustainability and well-being & $\begin{array}{l}\text { Build experiences for community } \\
\text { development and well-being }\end{array}$ \\
\hline Target & Knowledge, skills, and attitudes & $\begin{array}{l}\text { Knowledge, skills, attitudes, and } \\
\text { experience }\end{array}$ \\
\hline Vision & Community-centered & Experience-centered \\
\hline Principles & $\begin{array}{l}\text { - Networking } \\
\text { - Critical thinking } \\
\text { - Transformation }\end{array}$ & $\begin{array}{l}\text { - Autonomous thinking } \\
\text { - Critical reflection } \\
\text { - Perspective transformation }\end{array}$ \\
\hline Core competencies & $\begin{array}{l}\text { Attitudes, skills, and knowledge } \\
\text { to think critically }\end{array}$ & $\begin{array}{l}\text { Developing skills, experiences and } \\
\text { building capacities for transfor- } \\
\text { mation }\end{array}$ \\
\hline
\end{tabular}




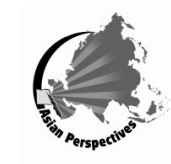

There are 71 Kominkans located in Hiroshima city, each Kominkan provides activities for different learning groups (see Table 2). As for April 2020, the total number of learning groups in the Kominkans of Hiroshima city was 3,709 groups.

Table 2 Learning group activities of Kominkans

*Source: The city of Hiroshima.

and population of Hiroshima city wards

${ }^{* *}$ Source: Hiroshima cultural foundation.

The activities of learning groups include education and training sessions; handcraft and life skills training; art and culture cultivation (including the traditional dance, penmanship and calligraphy, and music); sports and recreation; consultation on study; and volunteer activities, including machizukuri (community development) (Suzuki, Inoue, \& Oki 2015). There are many traditional activities such as origami (paper folding); ikebana (the Japanese art of flower arrangement); haiku and tanka (the Japanese form of short poetry in three phrases); folk dance; Kimono dressing; and kamishibai (Japanese street theatre and storytelling). Additionally, most of Kominkans have learning groups on local history.

The activities of learning groups can be classified into six categories: Lifelong learning and education; art and culture; crafts and cuisine; volunteer activities; recreation and sports (including health and fitness); and other (include the non-permanent activities, i. e. alcohol abstinence meetings). Table (3) shows the numbers of learning groups by wards.

\begin{tabular}{|l|l|l|l|}
\hline Ward & Population $^{*}$ & Kominkans $^{* * *}$ & Learning groups $^{* * *}$ \\
\hline Aki & 79,368 & 5 & 197 \\
\hline Asakita & 143,283 & 10 & 600 \\
\hline Asaminami & 244,393 & 10 & 753 \\
\hline Higashi & 120,519 & 7 & 417 \\
\hline Minami & 143,016 & 7 & 325 \\
\hline Naka & 135,379 & 4 & 295 \\
\hline Nishi & 189,277 & 9 & 518 \\
\hline Saeki & 140,337 & 19 & 604 \\
\hline
\end{tabular}




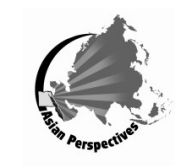

\section{Table 3 Categories of learning groups}

Note: in each cell, the total number of learning groups is above and the percentage is below.

\section{Discussion}

From the categories of learning groups in Hiroshima city's Kominkans, it is noticed that the category of art and culture recruits the highest percentage of learning groups, followed by recreation and sports, then lifelong learning and education. This reflects the traditional vision of Kominkan activities as hobbies and cultural activities (Murata \& Yamaguchi, 2010; Maruyama, 2011; Suzuki, Inoue, \& Oki, 2015). While the category of volunteer activities has received the least percentage of learning groups.

The high rate of participation in art and culture learning groups can be understood from the point of view of the community-based approach of transformation and ESD. Participants have the attitudes to commemorate their culture and traditions, especially Zen arts (Japanese traditional drums) and tea ceremony (Hendry, 2019). Furthermore, it is noticed that many families send their children to Kominkan to learn about their unique culture. Hence, they develop their knowledge and skills of a specific hobby or cultural activity. Moreover,

\begin{tabular}{|c|c|c|c|c|c|c|c|}
\hline & $\begin{array}{l}\text { Lifelong } \\
\text { learning }\end{array}$ & $\begin{array}{l}\text { Art and } \\
\text { culture }\end{array}$ & $\begin{array}{l}\text { Crafts and } \\
\text { cuisine }\end{array}$ & $\begin{array}{l}\text { Volunteer } \\
\text { activities }\end{array}$ & $\begin{array}{l}\text { Recreation } \\
\text { and sports }\end{array}$ & Other & Total \\
\hline Aki & $\begin{array}{l}19 \\
9.6 \%\end{array}$ & $\begin{array}{l}69 \\
35 \%\end{array}$ & $\begin{array}{l}27 \\
13.7 \%\end{array}$ & $\begin{array}{l}7 \\
3.55 \%\end{array}$ & $\begin{array}{l}75 \\
38.1 \%\end{array}$ & $\begin{array}{l}1 \\
0.5 \%\end{array}$ & 197 \\
\hline Asakita & $\begin{array}{l}74 \\
12.3 \%\end{array}$ & $\begin{array}{l}248 \\
41.3 \%\end{array}$ & $\begin{array}{l}72 \\
12 \% \\
\end{array}$ & $\begin{array}{l}37 \\
6.2 \%\end{array}$ & $\begin{array}{l}168 \\
28 \%\end{array}$ & $\begin{array}{l}1 \\
0.2 \%\end{array}$ & 600 \\
\hline $\begin{array}{l}\text { Asamin } \\
\text { ami }\end{array}$ & $\begin{array}{l}120 \\
15.9 \%\end{array}$ & $\begin{array}{l}288 \\
38.3 \%\end{array}$ & $\begin{array}{l}77 \\
10.2 \%\end{array}$ & $\begin{array}{l}28 \\
3.7 \%\end{array}$ & $\begin{array}{l}236 \\
31.4 \%\end{array}$ & $\begin{array}{l}4 \\
0.5 \%\end{array}$ & 753 \\
\hline Higashi & $\begin{array}{l}64 \\
15.3 \%\end{array}$ & $\begin{array}{l}167 \\
40.1 \%\end{array}$ & $\begin{array}{l}42 \\
10.1 \%\end{array}$ & $\begin{array}{l}31 \\
7.4 \%\end{array}$ & $\begin{array}{l}111 \\
26.6 \%\end{array}$ & $\begin{array}{l}2 \\
0.5 \%\end{array}$ & 417 \\
\hline Minami & $\begin{array}{l}31 \\
9.5 \%\end{array}$ & $\begin{array}{l}157 \\
48.3 \%\end{array}$ & $\begin{array}{l}37 \\
11.4 \%\end{array}$ & $\begin{array}{l}20 \\
6.2 \%\end{array}$ & $\begin{array}{l}79 \\
24.3 \%\end{array}$ & $\begin{array}{l}1 \\
0.3 \%\end{array}$ & 325 \\
\hline Naka & $\begin{array}{l}43 \\
14.6 \%\end{array}$ & $\begin{array}{l}143 \\
48.5 \%\end{array}$ & $\begin{array}{l}21 \\
7.1 \%\end{array}$ & $\begin{array}{l}13 \\
4.4 \%\end{array}$ & $\begin{array}{l}69 \\
23.4 \%\end{array}$ & $\begin{array}{l}6 \\
2 \%\end{array}$ & 295 \\
\hline Nishi & $\begin{array}{l}84 \\
16.2 \%\end{array}$ & $\begin{array}{l}207 \\
40 \%\end{array}$ & $\begin{array}{l}61 \\
11.8 \%\end{array}$ & $\begin{array}{l}23 \\
4.4 \%\end{array}$ & $\begin{array}{l}143 \\
27.6 \%\end{array}$ & 0 & 518 \\
\hline Saeki & $\begin{array}{l}79 \\
13.1 \%\end{array}$ & $\begin{array}{l}265 \\
43.9 \%\end{array}$ & $\begin{array}{l}67 \\
11.1 \%\end{array}$ & $\begin{array}{l}35 \\
5.8 \%\end{array}$ & $\begin{array}{l}156 \\
25.8 \%\end{array}$ & $\begin{array}{l}2 \\
0.3 \%\end{array}$ & 604 \\
\hline
\end{tabular}

they build their capacities and transform their experiences (perspective trans- 
formation).

Through reviewing the content of the activities of the before-mentioned categories, some key findings are arrived at:

- Kominkan activities meet all requirements to be described as community-based transformative learning because of two reasons: all learning groups aim at building participants' capacities; and perspective transformation is embodied in all learning groups.

- Kominkan activities meet all requirements to be described as community-based ESD because all learning groups aim at developing knowledge, skills, and attitudes to think critically.

- ESD activities might not be titled 'ESD...' as the majority of Kominkan learning groups are authentically titled by traditional names (i.e. $S a$ kura). Most of Kominkan activities are ESD activities in nature because it aims to sustainability and well-being.

- Integrating community-based transformative learning and communitybased ESD into one model might help to promote transformation and sustainability effectively.

\section{Conclusion and suggestions}

This research extends our understanding of community-based learning activities. Apparently, social education in Japan positions Kominkan activities in a distinctive category. However, the discourses on ESD and transformation seems to receive little attention in kominkans than formal education facilities. Further research is recommended to draw a clear image of comparing the formal and non-formal education settings.

Given that little research has examined the integration between transformative learning and ESD in the context of social education, this article contributes to knowledge about how community-based learning activities at Kominkan can engage learners and thus developing their aims of critical and transformative actions might be targeted.

The current research has few limitations, it neither provides the voices of Kominkans' staff member nor participation due to the hardness in accessing kominkans during the COVID-19 pandemic for safety reasons.

From the analysis of the case of Hiroshima city, the research findings indicate that at seven out of eight wards of Hiroshima city, art and cultural activi- 
ties appeal to more participants than other activities. Furthermore, volunteer activities do receive less participation, this paper suggests giving much attention to increasing participation in volunteer and machizukuri community development activities.

This research argued that Kominkan activities can develop an integrative form of both community-based transformative learning and community-based transformative ESD. Therefore, it suggests promoting transformation and sustainability through an integrative model that combines critical thinking and perspective transformation (see figure 1). Kominkans' managers, staff members, activity designers, and social education stakeholders and policymakers might consider this model for developing activities that promote transformation and sustainability.

Figure 1 Integrative model of community-based transformative learning and ESD

The proposed model consists of four steps for promoting societal transformation and sustainability through Kominkan activities, it integrates transformative learning and ESD principles in a dynamic process of four actions:

- Think: Either cultivating the critical thinking competence or responding to local community issues, utilizing skills, knowledge, and attitudes of critical thinking;

- Plan: Either cultivating the planning for action competence or networking with multi-stakeholders to plan for actions to respond to the local community issues identified;

- Transform: Directing practices towards a perspective transformation; and

- $\quad$ Sustain: Sharing powerful experiences to maintain long-term changes and sustainable societal achievements.

\section{References}

Books: the name(s) of the author(s) or editor(s); the title(s) of the publication; the name and location of the publisher(s); the date of publication.

- Journals: the name(s) of the author(s) or editor(s); the title(s) of the article; 
Journal name; Volume number (Issue or part number), first and last page numbers; the date of publication.

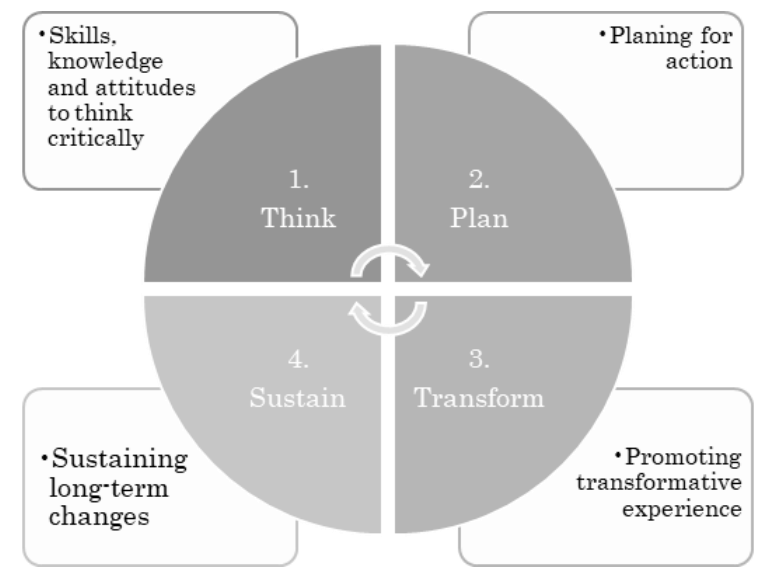

Blewitt, J., Understanding sustainable development, London: Earthscan, 2008.

Chikamori, K., Tanimura, C. \& Ueno, M., Transformational model of education for sustainable development (TMESD) as a learning process of socialization, Journal of Critical Realism, 18(4), pp. 420-436. 2019, https://doi.org/10.1080/14767430.2019.1667090

Cranton, P., Understanding and promoting transformative learning: A guide for educators of adults, San Francisco: Jossey-Bass, 2006.

Didham, R. \& Ofei-Manu, P., The role of education in the sustainable development agenda: Empowering a learning society for sustainability through quality education, In IGES, A chieving the sustainable development goals: From agenda to action, Hayama, Japan: Institute for Global Environmental Strategies, 2015.

Hendry, J., Understanding Japanese society. $5^{\text {th }}$ edition, New York: Routledge, 2019.

Illeris, K., Transformative learning and identity, New York: Routledge, 2014.

JNCU, For Further Promotion of Education for Sustainable Development (ESD), Japan: ESD Special Subcommittee, 2015.

Kawano, A., Matsuda, T. \& Xiao, L., Social education in Japan, Pedagogica Social, 27(1), pp. 253-280, 2016.

Kligyte, G., Transformation narratives in academic practice, International Journal for Academic Development, 16(3), pp.201-213, 2011. https:// doi.org/10.1080/1360144X.2011.596703

Maruyama, H., Social education system in Japan, Japan: National institute for educational policy research, 2009. 
Maruyama, H., Social education system in Japan. Japan, NIER, 2011, [Online] Retrieved on May 25th, 2018, from https://www.nier.go.jp/English/ educationjapan/pdf/201109LLL.pdf

Mejiuni, O., International and community-based transformative learning, In Taylor, E. W. \& Cranton, P. (Eds.), The handbook of transformative learning: Theory, research, and practice, pp. 304-319, San Francisco: Jossey-Bass, 2012.

Mezirow, J., Transformative learning: Theory to practice, In Cranton, P. (Ed.), Transformative learning in action: Insights from practice, San Francisco: Jossey-Bass, 1997.

Mezirow, J., Transformative learning Theory, In Mezirow, J. \& Taylor, E. W. (Eds.), Transformative learning in practice: Insights from community, workplace, and higher education, pp. 18-31, San Francisco: JosseyBass, 2009.

Mezirow, J. \& Taylor, E. W., Transformative learning in practice: Insights from community, workplace, and higher education, San Francisco: JosseyBass, 2009.

Mezirow, J., Learning to think like an adult: Core concepts pf transformation theory, In Taylor, E. W. \& Cranton, P. (Eds.), The handbook of transformative learning: Theory, research, and practice, pp. 73-95, San Francisco: Jossey-Bass, 2012.

Mochizuki, Y., Top-down and bottom-up ESD: Divergence and convergence of Japanese ESD discourses and practices, In Singer, J. et al. (Eds.), Educating for sustainability in Japan, pp. 1-24, New York: Routledge, 2017.

Murata, K. \& Yamaguchi, M., Education in contemporary Japan: System and content, Tokyo: Toshindo Pub, 2010.

Noguchi, F., Guevara, J. R. \& Yorozu, R., Communities in A ction: Lifelong Learning for Sustainable Development, Hamburg: UNESCO Institute of Lifelong Learning (UIL), 2015. http://bit.ly/1NxGncP

Okano, K., Nonformal education in Japan: Its interface with formal schools, In, Okano, K. (Ed.), Nonformal education and civil society in Japan, New York: Routledge, 2016.

Oyasu, K. \& Riewpituk, D., CLCs in Asia-Pacific region, In Okayama ESD Promotion Commission, UNESCO Chair at Okayama University (Eds.), Education for sustainable development and Kominkan/ community learning centre: Promotion of ESD by utilizing Kominkan/ CLC, Okayama University Press, 2013.

Rogers, A., Second-generation non-formal education and the sustainable development goals: operationalising the SDGs through community learning centres, International Journal of Lifelong Education, 38(5), pp. 515-526, 2019. https://doi.org/10.1080/02601370.2019.1636893 
Saffa M. \& Jabbie M., Developing Transformational Competencies for Sustainable Development, In Leal Filho W., et al. (Eds.), Quality education: Encyclopedia of the UN sustainable development goals, Cham: Springer, 2020.

Schnitzler, T., The bridge between education for sustainable development and transformative learning: Towards new collaborative learning spaces, Journal of Education for Sustainable Development, 13(2), pp. 242253, 2019. https://doi.org/10.1177/0973408219873827

Souza, D. T., Wals, A. E. J. \& Jacobi, P. R., Learning-based transformations towards sustainability: a relational approach based on Humberto Maturana and Paulo Freire, Environmental Education Research, 25(11), pp. 1605-1619, 2019. https://doi.org/10.1080/13504622.2019.1641183

Summers, D., \& Cutting, R., Education for sustainable development in further education, London: Palgrave Macmillan, 2016.

Suzuki, M., Inoue, N. \& Oki, M., (ed.)『社会教育の施設論 : 社会教育の空 間的展開を考える』,Facilities of social education: understanding the spatial development of social education, Tokyo: Gakubunsha, 2015.

Taimur S. \& Sattar H., Education for sustainable development and critical thinking competency, In Leal Filho W., et al. (Eds.), Quality education: Encyclopedia of the UN sustainable development goals, Cham: Springer, 2020.

Tanaka, H., Education for sustainable development and development education in Japan: ESDRC working paper, Rikkyo University: Education for sustainable development research center, 2009. [Online]. Retrieved June 27, 2018, from https://www2.rikkyo.ac.jp/web/esdrc/products/ tanaka en-2.pdf

Tanaka, H., Current State and Future Prospects of Education for Sustainable Development (ESD) in Japan, Educational Studies in Japan: International Yearbook, (11), pp. 15-28. 2017.

The City of Hiroshima, Statistics, 2020, Available at: https:// www.city.hiroshima.lg.jp/site/toukei/

UN., Transforming our World: The 2030 Agenda for Sustainable Development. Resolution adopted by the General Assembly on 25 September 2015, UN, 2015. Available at: http://www.un.org/ga/search/view doc.asp? symbol $=\mathrm{A} / \mathrm{RES} / 70 / 1 \&$ Lang $=\mathrm{E}$

UNESCO., Roadmap for Implementing the Global Action Programme on Education for Sustainable Development, Paris: UNESCO, 2014.

UNESCO., What is ESD, 2020, Available at: https://en.unesco.org/themes/ education-sustainable-development/what-is-esd

UN-WCED., Our common future, 1987, Retrieved April 1, 2019, from http:// www.un-documents.net/ocf-02.htm 
Wals, A. E. J., Mirroring, Gestaltswitching and transformative social learning: Steppingstones for developing sustainability competence, International Journal of Sustainability in Higher Education, 11 (4), pp. 380-390, 2010. https://doi.org/10.1108/14676371011077595

Wals, A. J., Mochizuki, Y., \& Leicht, A., Critical case-studies of non-formal and community learning for sustainable development, International Review of Education Journ 